\title{
Kingsbury Brunetto, K. (2015). Performing the Art of Language Learning: Deepening the Language Learning Experience through Theatre and Drama. Blue Mounds, WI: Deep University Press.
}

\section{Serafina Morrin}

In this book, Kingsbury Brunetto describes her research on the language learning experience through theatre. Doing so, she analyses interviews with undergraduate students, which she collected from two theatre-based language courses (French and Spanish as L2) at different survey dates. The focus lies on the use of language as a social act that demonstrates the multifaceted nature of theatre-based language learning. Language is not only seen as something shown in evident linguistic objects here; rather it is a result of activities in complex contexts.

The author wants to find out how learners of a second language function within a theatre-based language learning environment. She tries to understand the complexity of language learning as a socially situated human activity by looking at the perspectives of the participants. The particular charm of the book is that it is structured like a theatre play. Kingsbury Brunetto refrains from classic terms such as "theoretical background" or "research method", and instead entitles the chapters analogously to the procedure for a theatre performance, such as "Playbill", "Before the Curtain Rises" or "The Critics' Reviews".

In the beginning, Kingsbury Brunetto presents her approach to this research by briefly sketching her own background and providing a short insight into the theoretical arguments for language learning through theatre. This is followed by "Playbill", where she specifies her field of research, the setting and the interview participants, whom she calls the "Cast of Characters". The data were collected in two courses, one for French and one for Spanish, with a total of eight undergraduate university students. The core of the pilot study (the French class) is the interviews of two participants with only one date of inquiry. The main investigation is conducted in the Spanish course, where six participants are interviewed in a series of three interviews. The first interview at the beginning of the class focuses on the biographical background of the interviewees, the second on the details of their experience and the last one, at the end of the course, is concerned with a reflection on meaning.

Kingsbury Brunetto explains the methodology on which her research is based in a comprehensible and detailed manner. She describes her phenomenological approach as trying to have an "illusion of the first time" (p.35), meaning that 
the researcher, despite her personal background knowledge, aims to look at a topic with "fresh eyes" (p.36). Furthermore, she specifies her own role in this process and considers biases and assumptions. In her methodology, she refers to van Manen (1997), who conceives storytelling and anecdotes as data, because this is how people give structure to their lived experiences. Such a narrative approach can offer insights into implicit logic.

In the chapter "Backstage", the author outlines the theories of van Lier (2000, 2002, 2004, 2010), who regards language development from an ecological approach as something emergent, dynamic and socially situated. This coincides with social aspects of language learning in which Bakhtin (1986) frames "language as contextualised utterances that exist in an embedded relationship with previous and subsequent utterances" (as cited in Kingsbury Brunetto 2015: 18). Bakhtin considers utterances to not only be positioned between the characters but also between the playwright and the public. He regards an individual work of literature not as a definite entity but rather as a dialogue that refers to previously and subsequently generated language. This is in accordance with the theory of van Lier (2000), whereby language learning is something that rests neither in the learners themselves nor in the objects, but emerges in the interaction. This entails, in meaningful interactions, that there is no single way a language can be used, which shifts the concept of communication away from a monolingual habitus (Gogolin 1989).

In the discussion of the results, the social dimensions of the interviewees are considered extensively. The author finds that within the process, it becomes more natural for the participants to interact socially in the target language and, ultimately, feel less intimidated. In addition, the participants describe a suspension of hierarchy among the students. They assert that the role of the professor is not omniscient and in that regard the hierarchy changes as well. Referring to the terms of Bakhtin (1981), the data show that this kind of learning process implies a transition from a framework of authoritative discourse to an internally persuasive one, which allows the participants to also disagree with their professor.

It appears that a freedom of communication is developed in both courses, because the students want to be understood by others, rather than to correctly express themselves linguistically. In this process, silent and shy students find a voice and classmates become friends. This allows more risk taking, promotes the gaining of self-confidence and the embracement of new challenges. Through this collective process, a situated learning environment is achieved. Another category that Kingsbury Brunetto explores is the fact that through engaging with the text, new understandings and meaning-making occurs performatively within the interactions.

It becomes apparent that by acting something out and with the help of an interactive process of revisiting the text, a deeper understanding of the literature is gained and the comprehension is gradually refined. Simply reading the text seems to leave many nuances concealed. But in a scenic interaction, the written text gains a more complete picture. The participants discover that 
they also have to react to the lines of the others. Conceptualising the characters in deeper detail helps to incorporate the meaning of language.

Because the actors on stage have to rehearse within material limitations (size of stage, costumes, props) and not with the idealised settings they may have initially imagined, they are obliged to find solutions. This playful experimentation frequently leads to the incorporation of extra creative touches. Another outcome of the survey concerns the role of the class instructor, which becomes de-centred from a traditional one. This leads to solidarity among the group members. For instance, the participants describe the importance of collaboration in their interviews, with every member making a substantial contribution in the process.

Furthermore, Kingsbury Brunetto refers to the concept of metaxis, which she describes

as an ecstatic state in which participants stand outside of themselves as they are absorbed into the fictitious world of the play. Through metaxis, participants collaboratively create and enter into an unreal world (p. 165).

This can be seen as a mimetic process that helps to embody language not only by an explicable cognitive process but also by a tacit relating to memories and personal experiences as a corporal reference. Accordingly, Blair (2008: 110) sees the neural net as something that not only works as cognition, but "that holds memories and personal histories and experience, and the way that language works on and through the body". This also entails that the emotional impact on the character can have an emotional impact on the lived world of the participants. Immersion in the character may also be fostered by costumes, lighting, sounds and the use of props. Here, Kingsbury Brunetto refers again to the concept of an ecological framework by van Lier. By way of example, holding a weapon helps one of the participants embody a native warrior.

In addition to the focus on language learning as a social and interactive process, the author explores linguistic aspects. The interviewees confirm their progress in pronunciation as well as their motivation to improve their L2 proficiency. They talk about using memorised utterances from the text in their spontaneous language production. Using pre-existing utterances helps the students not think about the construction of the foreign language, but instead be able to speak aloud without becoming nervous and to dedicate more attention to infusing their words with emotion and expression.

Target language theatre helps to find and create a niche that can satisfy the individual skills of the language learner and their linguistic needs, rather than trying to adjust to a one-size-fits-all syllabus. Doing so, this language learning method may be used to implement differentiated tasks that can be tailored to the individual participants. At first, it might be difficult to find a suitable script where the enrolled students match the characters in the play. But, by referring to the ecological framework of van Lier (2000, 2002, 2004, 2010), Kingsbury Brunetto argues that the students constitute a network of affordance within 
which participants establish relationships and are able to derive what they need for their development based on what is available. In conclusion, she argues that "learning takes place through the actual exploration of the performance in rehearsal, but not in an abstract studying of the target culture" (p.214).

This research work is important insofar as theatre-based language learning currently occupies a marginal position in the world language curriculum. Kingsbury Brunetto shows in her book that conveying language knowledge requires consideration of the social aspects of a context-dependent interaction, where a rich and deep understanding of a text can be promoted through drama and theatre. Wittgenstein once commented that the meaning of a word is its use in the language (Wittgenstein 2003: 40).

In this work, Kingsbury Brunetto verifies plausibly why and how the method of drama and scenic play can foster language learning. Because of its reader-friendly structure, it is aimed not only at the scientific community as such, but specifically at language instructors. It gives the reader an insight into the practical implementation aspects, and at the same time calls for reflections on their own work. The interview quotations and the ample descriptions exemplify not only "why it makes sense" but also "how it is done" and encourages emulation.

Language learning, as indeed learning in general, needs to be approached as a socially situated process. But the question arises whether the social aspects mentioned, such as self-efficacy, cannot also be supported by other project-oriented learning methods, where the students are obliged to find solutions in a team or demolish hierarchal structures. Are there not numerous other ways in which the content of a curriculum can be set in differing social and cultural contexts, or in learning environments in which there are not only evident learning outcomes, but where the students also gain a deeper meaning in terms of the content? Yes, there certainly are. However, what the data also demonstrates, which is not mentioned explicitly, is the importance of aesthetic experiences in the field of pedagogy. Aesthetic experiences cannot be enforced by a special learning programme. But a creative learning environment, such as a theatre play where the actors can linger in a specific atmosphere or within a certain perception of time and space, can allow aesthetic experiences to occur.

The results of this study demonstrate extensively that language has a social and context-dependent dimension. Moreover, this dimension can be viewed as confirmation of a corporal-mimetic and performative perspective in language, which needs to be considered further in language learning as indeed in other pedagogical practice.

\section{Bibliography}

Bakhtin, Mikhail (1981): The dialogic imagination. Holquist, M. (Ed.). Austin: University of Texas Press 
Bakhtin, Mikhail (1986): Speech genres and other late essays. Emmerson, C. \& Holquist, M. (Ed). Austin, TX: University of Texas Press

Blair, Rhonda (2008): The actor, image, and action: Acting and cognitive neuroscience. London Routledge.

Gogolin, Ingrid (1998): The "monolingual habitus" as the common feature in teaching language of the majority in different countries. In: Per Linguam, $13 / 2,38-49$

Van Lier, Leo (2000): From input to affordance: Social-interactive learning from an ecological perspective. In: Lantolf, J. (Ed.). Sociocultural theory and second language learning. Oxford: University Press. 245-259

Van Lier, Leo (2002): An ecological-semiotic perspective on language and linguistics. In: Kramsch, C. (Ed.). Language acquisition and language socialization: Ecological perspectives. London: Continuum. 140-164

Van Lier, Leo (2004): The ecology and semiotics of language learning: A sociocultural perspective. Boston: Kluwer Academic Publishers

Van Lier, Leo (2010): Agency, self, and identity in language learning. In: O’Rourke et al. (Eds.). Language learner autonomy: Policy, curriculum, classroom. Oxford: Peter Lang

Van Manen, Max (1997): Researching lived experience: Human science for an action-sensitive pedagogy. London: Althouse Press

Wittgenstein, Ludwig (2003): Philosophische Untersuchungen (reprinted by J. Schulte). Frankfurt am Main: Suhrkamp 